\title{
Management of crotalaria and pigeon pea for control of yam nematode diseases
}

\author{
Marlon da Silva Garrido ${ }^{1}$, Ana Cristina Fechino Soares ${ }^{1}$, João Luiz Coimbra ${ }^{2}$, Carla da Silva Sousa ${ }^{1}$
}

${ }^{1}$ Centro de Ciências Agrárias, Ambientais e Biológicas, Programa de Pós-Graduação em Ciências Agrárias, Laboratório de Fitopatologia e Microbiologia Agrícola, Universidade Federal do Recôncavo da Bahia, CEP 44380-000, Cruz das Almas, BA. ²Dep. Ciências Humanas, Campus IX, Universidade Estadual da Bahia, CEP 47800-040, Barreiras, BA.

Autor para correspondência: Ana Cristina Fechino Soares. acsoares@ufrb.edu.br

Data de chegada: 13/06/2005. Aceito para publicação em: 15/04/2008

\section{ABSTRACT}

Garrido, M. da S.; Soares, A.C.F.; Coimbra, J.L.; Sousa, C. da S. Management of crotalaria and pigeon pea for control of yam nematode diseases. Summa Phytopathologica, v.34, n.3, p.222-227, 2008

Management of plant-parasitic nematodes with the use of nematicides has not been recommended for small farmers that grow yam in the Northeastern region of Brazil, due to its high cost and residue toxicity. The use of plants with antagonistic effect to nematodes and green manure which improves soil chemical, physical and biological characteristics can be a viable and low cost alternative to control parasitic nematodes. This work aimed to evaluate the effect of crotalaria (Crotalaria juncea) and pigeon pea (Cajanus cajan) plants on the control of yam nematodes. Three experiments were carried out. The first was conducted under in vitro conditions to evaluate the nematostatic and nematicide effect of extracts from fresh and dry matter of the above ground parts of crotalaria, pigeon pea, and the combination of both. The second experiment was carried out under greenhouse conditions to evaluate the effect of soil amendment with crotalaria, pigeon pea, and the combination of both in the infectivity of Scutellonema bradys, using tomato plants as the host plant. The third experiment was conducted under field conditions to evaluate the effect of crotalaria, pigeon pea, and the combination of both, cultivated between yam planting rows and incorporated to soil surface, on yam nematodes. The aqueous extract obtained form fresh matter of crotalaria had a nematicide effect of $100 \%$ for S. bradys. Extracts from dry matter of both crotalaria and pigeon pea did not have any nematicide effect, but had a nematostatic effect. Incorporation of crotalaria to soil inhibited infectivity of $S$. bradys in tomato seedlings. These results showed that planting crotalaria alone or in combination with pigeon pea, between the yam planting rows, is an efficient method for controlling S. bradys and Rotylenchulus reniformis associated with yams. Crotalaria can be used for controlling these plant-parasitic nematodes in soil.

Additional keywords: Scutellonema bradys, Rotylenchulus reniformis, Crotalaria juncea, Cajanus cajan

\section{RESUMO}

Garrido, M. da S.; Soares, A. C. F.; Coimbra, J. L.; Sousa, C. da S. Manejo da crotalária e do guandu no controle de nematoses do inhame. Summa Phytopathologica, v.34, n.3, p.222-227, 2008

O manejo de fitomenatóides com o uso de nematicidas não tem sido indicado para os pequenos produtores de inhame do Nordeste do Brasil pelo seu alto custo e riscos a saúde. A utilização de plantas, com efeito, antagônico a fitonematóides e de adubos verdes que melhoram as características químicas, físicas e biológicas do solo, pode ser uma alternativa viável e de baixo custo para o controle de fitonematóides por pequenos produtores. Este trabalho teve como objetivo, avaliar o efeito da crotalaria (Crotalaria juncea) e do feijão guandu (Cajanus cajan) no controle das nematoses associadas à cultura do inhame. Foram montados três ensaios, sendo o primeiro in vitro, para avaliar o efeito nematóstatico e nematicida do extrato da matéria seca e fresca da parte aérea da crotalária, do guandu e da combinação de ambos; o segundo, em casa de vegetação para avaliar o efeito da incorporação ao solo da parte aérea de crotalária, de guandu e da combinação de ambos, na infectividade do Scutellonema bradys, utilizando-se o tomateiro como planta hospedeira, e o terceiro experimento foi conduzido no campo, para se avaliar o efeito do cultivo e incorporação da crotalária, do guandu e da combinação de ambos, nas entrelinhas do plantio de inhame, no manejo de nematóides associados a esta cultura. O extrato da matéria fresca da parte aérea de crotalária proporcionou um efeito nematicida de $100 \%$ para S. bradys. Os extratos da matéria seca da parte aérea de ambos, guandu e crotalária, não apresentaram efeito nematicida, mas apenas nematostático. A incorporação da parte aérea da crotalária ao solo inibiu a infectividade do $S$. bradys em mudas de tomateiro. O plantio da crotalária solteira ou associada ao guandu, nas entrelinhas do inhame, demonstrou ser eficiente no controle de $S$. bradys e de Rotylenchulus reniformis, podendo a crotalária ser utilizada para o controle destes fitonematóides no solo. 
The yam 'da Costa' (Dioscorea Cayennensis Lam.) is a crop that is susceptible to the attack of important plant-parasitic nematodes (15), especially Scutellonema bradys (Steiner and Le Hew) Andrassy, Pratylenchus coffea (Zimmerman) Filipjen, Meloidogyne incognita (Kofoio and Hitwood white), and Rotylenchuslus reniformis Linford and Oliveira, that are responsible for great damage to yam tubers (17, 19, 12).

S. bradys and Pratylenchus sp. penetrate into tubers outer layer, forming galleries during the feeding and reproduction processes, causing necrosis known as dry rot (18). These plant-parasitic nematodes affect the productivity, quality and commercial value of yam tubers in the Northeastern region of Brazil $(17,11)$.

These nematodes are disseminated by tuber-seeds and their control is difficult for small farmers in Brazil, due to high cost of nematicides and low level of technology used by small farmers (13). Tubers with dry rot symptoms lose moisture quickly, become predisposed to infection by secondary microorganisms, and lose quality and commercial value, becoming inadequate for exportation (1).

The control of nematodes, especially of $S$. bradys and Pratylenchulus sp. in yam tubers is limited to chemical and physical methods (16). However, the utilization of fumigating nematicides and systemic pesticides is not recommended in Brazil for the yam crop due to toxicological and economical reasons (17). Nematode control with hydrothermic treatment of tubers-seeds is an alternative method, which also presents restrictions due to the difficulties encountered by small farmers in using this method (16).

Cultural control with the use of plants antagonistic to nematodes, such as crotalaria, has been demonstrated to be a promising method for nematode control in the field $(10,22)$. This plant is known for its toxic properties to nematodes (21). In yam 'da Costa' plantations in the State of Pernambuco, C. juncea reduced the population of $P$. coffea and $R$. reniformis in soil after two years of rotation (19). Another important method for control of plant parasitic nematodes is the addition of organic matter of animal or plant origin to soil, which promotes growth of antagonistic microorganisms and predators to nematodes $(6,4,24)$.

Pigeon pea (Cajanus cajan) and crotalaria (Crotalaria juncea) are used as green manure crops because of their association with nitrogen fixing bacteria and high shoot dry mass production, which can promote significantly improvements in soil physical, chemical and biological properties $(3,5)$. However, little is known about the employment of these green manure crops for controlling $S$. bradys in yams cultivated in the Recôncavo region of the State of Bahia, Brazil (12). This work aimed to evaluate the effect of crotalaria and pigeon pea on the control of nematodes associated with yam crop.

\section{MATERIALS AND METHODS}

Three experiments were carried out. The first was conducted with in vitro assays to evaluate the nematostatic and nematicide effect of crotalaria and pigeon pea aqueous extracts of above ground plant parts on S. bradys; the second was conducted under greenhouse conditions to study the infectivity of $S$. bradys in soil incubated with crotalaria and pigeon pea, and the third was conducted in the field to evaluate the effect of crotalaria and pigeon pea intercropped with yam and incorporated to soil surface in controlling S. bradys in a yam plantation.

Experiment 1. In vitro assays with extracts from dry and fresh crotalaria and pigeon pea above ground parts

\section{Nematode inoculum}

The inoculum of $S$. bradys was obtained from yam tubers infected with $S$. bradys, collected in yam plantations in the municipality of "Cruz das Almas", State of Bahia. For nematode isolation, the yam tuber superficial layers were removed with a knife, cut into small pieces and mixed in a blender with water, followed by centrifugal flotation with a sucrose solution, as described by Coolen and D’Herde (9).

The nematode suspension was quantified in a Peters Chamber, under a light microscope. For taxonomic identification of S. bradys, semi-permanent slides were mounted, using formalina $3 \%$ as mounting liquid and permount as a sealer.

\section{Plant extracts}

The aqueous extracts were obtained from fresh and dry matter of aerial parts of Crotalaria juncea 'IAC-KR1' variety, pigeon pea (Cajanus cajan) 'Fava larga' variety, and a mixture of 50\% Crotalaria juncea and $50 \%$ pigeon pea (wt/wt). The dry matter was obtained by drying plant aerial parts in an oven at $65^{\circ} \mathrm{C}$, until constant weight was obtained. Twenty grams of dry matter from each plant material were added to $40 \mathrm{~mL}$ of distilled water in a beaker, boiled for three minutes and filtered through cheese cloth. The extracts from plant fresh matter were obtained by adding $20 \mathrm{~g}$ of fresh aerial parts of crotalaria, pigeon pea, and Crotalaria juncea + pigeon pea to $40 \mathrm{~mL}$ of distilled water, mixed in a blender for 2 minutes and subsequently filtered through a cheese cloth.

\section{Bioassays with nematodes and plant extracts}

To evaluate the effect of dry and fresh matter plant extracts prepared as described above, on the motility and mortality of S. bradys, assays were conducted in ELISA type plates with 90 wells. Each plate well received $200 \mu 1$ of the plant extract and 20 nematodes. Tap water was used in the wells for the control treatment. The plates were sealed with plastic film and incubated in a B.O.D. growth chamber, at $25^{\circ} \mathrm{C}$. After 24 hours, nematode motility was observed under a light microscope and the immobile nematodes (those that did not move or present a straight line or twisted body aspect were considered immobile) were counted and transferred to plate wells with tap water, which were incubated for 24 hours in a B.O.D. chamber, at $25^{\circ} \mathrm{C}$. Nematodes that did not recover their motility after incubation for 24 hours in water were considered dead. The assays were conducted in a randomized experimental design with four replications.

Experiment 2. Incorporation of crotalaria and pigeon pea fresh matter to soil and its effect on infectivity of $S$. bradys.

Tomato plants were used in this experiment, because they are host plants for $S$. bradys and are easy to growth under greenhouse conditions. Tomato seeds of 'Santa Cruz Kada' variety were sown in disposable plastic cups of $500 \mathrm{~cm}^{3}$ capacity, with $400 \mathrm{~cm}^{3}$ of a mixture of soil and sand (3:1, v/v) and with crotalaria and pigeon pea aerial parts added as described for the treatments. The following treatments were evaluated: T1 Control in soil without green manure, T2 Soil with incorporated aerial parts of crotalaria, T3 Soil with incorporated aerial parts of pigeon pea, and T4 Soil with incorporated aerial parts of a mixture of $50 \%$ crotalaria and $50 \%$ pigeon pea. For treatments $\mathrm{T} 2$, $\mathrm{T} 3$, and $\mathrm{T} 4,2 \%$ of fresh aerial plant parts were incorporated to soil at a depth of $3 \mathrm{~cm}$ from soil surface.

The experimental design was completely randomized with ten replications and two plants per replication, in a $4 \times 2$ factorial scheme with four treatments and two periods of evaluation (20 and 40 days 
after nematode inoculation). The tomato plants were inoculated by injecting $2 \mathrm{~mL}$ of an aqueous suspension with 4000 nematodes into the soil around plant roots using a $5 \mathrm{ml}$ pipette, 15 days after seed germination. The plants were collected at 20 and 40 days after nematode inoculation. At harvest, aerial plant parts were cut and soil was carefully removed from the roots. Soil samples from all treatments were immediately processed for nematode isolation by the sieving method followed by centrifugal flotation in a sucrose solution (14). Roots from each plant were carefully washed in running water, cut into small pieces, mixed in a blender with water and subjected to centrifugal flotation in a sucrose and kaolim solution (9). For nematode quantification, the aqueous suspensions of nematodes were transferred to a chamber and nematodes were counted under a light microscope. For verification of nematode parasitism, tomato roots were stained with acid fuchsin, as described by Bird et al. (8), placed between two glass slides and observed under a light microscope.

Experiment 3. Yam planting systems with crotalaria and pigeon pea

The experiment was conducted at Sitio São Carlos, in the municipality of Maragojipe, State of Bahia, Brazil, localized at 12.79907 S and 39.03992 W of Greenwich, in soil classified as 'Latossolo Vermelho-Amarelo álico coeso'. The soil presented the following chemical characteristics: $\mathrm{pH}_{\mathrm{H} 2 \mathrm{O}}=4.9$, available $\mathrm{P}=1 \mathrm{mg} \cdot \mathrm{dm}-$ ${ }^{3}, \mathrm{~K}=51 \mathrm{mg} \cdot \mathrm{dm}^{-3}, \mathrm{Ca}=0.75 \mathrm{cmol}_{\mathrm{c}} \cdot \mathrm{dm}^{-3}, \mathrm{Mg}=0.45 \mathrm{cmol}_{\mathrm{c}} \cdot \mathrm{dm}^{-3}, \mathrm{Al}=$ $0.2 \mathrm{cmol} \cdot \mathrm{dm}^{-3}, \mathrm{Na}=0.008 \mathrm{cmol} \cdot \mathrm{cm}^{-3}$ and $\mathrm{MO}=17 \mathrm{~g} \cdot \mathrm{kg}^{-1}$. The mean pluviometric regime of the region is $1500 \mathrm{~mm}$ year-1, with a regular distribution throughout the year.

Twelve tons per hectare of cattle manure were utilized, as recommended by Santos (20). The planting system used was on beds of $0.5 \mathrm{~m}$ height, with plant spacing of $1.20 \mathrm{~m}$ between planting rows and $0.40 \mathrm{~m}$ between plants, giving a plant density of 20000 plants per hectare. For sowing, tuber-seeds were sliced transversally into pieces of approximately $5 \mathrm{~cm}$ wide and each slice was further cut into three equal parts. The tuber heads were excluded, because they germinate faster than the other parts, and therefore, would cause an irregular field crop. Sowing was carried out in December of 2003 and harvesting occurring in November of 2004. The following treatments were evaluated: T1 Conventional yam planting; T2 Yam intercropped with crotalaria (Crotalaria juncea L., 'IAC-KR1' cultivar) between planting rows; T3 Yam intercropped with pigeon peas (Cajanus cajan L., 'Fava larga' cultivar) between planting rows; and T4 Yam intercropped with a combination of crotalaria and pigeon pea between planting rows. In the intercropped systems crotalaria and pigeon pea were sown between yams rows, in double rows $25 \mathrm{~cm}$ apart, with 10 plants per linear meter. For treatment 4 the double rows were comprised of individual rows of crotalaria and pigeon pea. The green manure crops were sown 30 days after yams sowing, and its cutting and incorporation to soil surface occurred 60 days after sowing. The experimental design was in randomized blocks, with four replicates and 10 pants per experimental plot. Four soil subsamples were taken at each experimental plot, at a soil depth of 0 to $20 \mathrm{~cm}$ to determine the population of soil plant-parasitic nematodes. Yam tubers were harvested six months after sowing (period of early harvesting, known as 'capação' in the State of Bahia) and at the end of the crop cycle (period of full tuber maturity). In addition, root samples from crotalaria and pigeon pea were collected in all experimental plots for isolation and quantification of root nematodes. For nematode quantification, the surface layers of yam tubers and roots of crotalaria and pigeon pea were cut into small pieces, mixed in a blender with water and submitted to centrifugal flotation with sucrose and kaolim solution, as described by Coolen \& D'Herde (9). Nematodes from soil samples were isolated by using the sieving method followed by centrifugal flotation with sucrose solution, as described by Jenkins (14). Nematode counting was done under a light microscope, with a Peter chamber.

\section{Statistical analysis}

Data in percentages were transformed into arc sen $\sqrt{x / 100}$ and counting data were transformed into (7). The data were submitted to variance analysis (ANOVA) and mean comparisons by the Tukey Test at $5 \%$ probability level. The data were analyzed with the statistic SAS (2000) software.

\section{RESULTS AND DISCUSSION}

Extracts from aerial parts dry matter of pigeon pea, crotalaria and pigeon pea + crotalaria presented $100 \%$ nematostatic effect for Scutellonema bradys, differing significantly from the control treatment in water. However, a nematicide effect of these plant extracts was not observed (Table 1). When the extract of fresh material of the aerial plant parts was used, $100 \%$ nematostatic effect was also observed for $S$. bradys, which differed significantly from the control treatment. The greater nematicide effects were observed in the treatments with crotalaria and the mixture of both (pigeon pea + crotalaria), which caused 100 and $84 \%$ of nematode mortality, respectively, followed by the treatment with pigeon pea with $41 \%$ of nematode mortality (Table 1). These results suggest that the chemical compound present in crotalaria, which has a nematicide effect can be volatile or thermosensitive and, therefore, is lost during the drying process and/ or boiling of plant aerial parts. The monocrotaline is a pyrrolizidine

Table 1. Effect of fresh and dry matter extracts of crotalaria (Crotalaria juncea) and pigeon pea (Cajanus cajan) aerial parts on motility and mortality of Scutellonema bradys.

\begin{tabular}{lcccc}
\hline & \multicolumn{2}{c}{ Dry matter extracts } & Fresh matter extracts \\
\cline { 2 - 5 } Treatments & Immobility & Mortality & Immobility & Mortality \\
\cline { 2 - 5 } & & & $(\%)$ & $11 \mathrm{c}$ \\
Control & $20 \mathrm{~b}$ & $29 \mathrm{a}$ & $12 \mathrm{~b}$ & $100 \mathrm{a}$ \\
Crotalaria & $99 \mathrm{a}$ & $33 \mathrm{a}$ & $100 \mathrm{a}$ & $41 \mathrm{~b}$ \\
Pigeon pea & $100 \mathrm{a}$ & $27 \mathrm{a}$ & $100 \mathrm{a}$ & $84 \mathrm{a}$ \\
Pigeon pea + Crotalaria & $100 \mathrm{a}$ & $37 \mathrm{a}$ & $100 \mathrm{a}$ & 16.31 \\
\hline $\mathrm{CV}(\%)$ & 8.17 & 30.71 & 1.85 & \\
\hline
\end{tabular}

The same letters in the columns do not differ statistically, by the test of Tukey at 5\% probability. 
alkaloid with a nematicide effect, which is exsudated from crotalaria roots and is also present in high concentrations in the aerial part of this plant (21).

The extract from pigeon pea aerial parts dry matter presented a nematostatic effect causing $41 \%$ mortality of $S$. bradys, suggesting that this plant may also have chemical compounds with nematicide properties. However, in the scientific literature, information on chemical compounds from pigeon pea with nematicide effects was not found, nor was information found on the use of pigeon pea for controlling plant-parasitic nematodes.

The use of extracts from $C$. juncea aerial parts fresh matter for control of $S$. bradys can be a low cost alternative that can easily be employed by yam farmers.

Wang et al. (21) when studying the effect of an extract from aerial parts of $C$. juncea fresh matter for control of $R$. reniformis, verified that the extract was more efficient when added 48 hours before nematode inoculation.

In the greenhouse study with soil amended with plant fresh biomass (crotalaria, pigeon pea, and crotalaria combined with pigeon pea) to evaluate the infectivity of $S$. bradys on tomato plants (Figure 1), it was observed that the treatments with amendment of fresh crotalaria aerial parts and crotalaria combined with pigeon pea, presented the lowest numbers of nematodes infecting the roots, while the treatment with soil amended with pigeon pea only and the control treatment with soil without the plant material presented the highest numbers of nematodes infecting the tomato roots, 20 days after nematode inoculation (Table 2). Similar results were obtained for the evaluation of root nematode infectivity at 40 days after inoculation (Table 2). It was observed that the number of nematodes infecting tomato roots was significantly higher at 40 days after inoculation (Table 2), which could be due to the life cycle of the nematode which is of 21 days (15). $S$. bradys was not observed in soil samples for all treatments, which may suggest a low survival capacity of this plant-parasitic nematode in soil.

In the field work, significant differences were observed in the number of nematodes infecting yam fine roots. In the yam planting system intercropped with crotalaria and with crotalaria combined with pigeon pea, the lowest mean values of yam root infection with $S$. bradys and $R$. reniformis were observed (Table 3 ). The conventional yam planting system, and the intercropped system with pigeon pea between yam planting rows presented the highest number of nematodes infecting yam fine roots.

These results confirm the nematicide effect of crotalaria and demonstrate the potential for employing this green manure crop for controlling yam parasitic nematodes. In the evaluation of nematode population densities in crotalaria and pigeon pea roots, it was observed that pigeon pea is a host plant for $R$. reniformis, but when combined with crotalaria the nematicide effect of crotalaria inhibited root

Table 2. Effect of fresh aerial parts of crotalaria and pigeon pea incorporated to soil surface on the infectivity of Scutellonema bradys in tomato roots, 20 and 40 days after nematode inoculation.

\begin{tabular}{lcc}
\hline \multirow{2}{*}{ Treatments } & $\mathbf{2 0}$ days & $\mathbf{4 0}$ days \\
\cline { 2 - 3 } & (number of nematodes per gram of roots) \\
\hline Control & $25.6 \mathrm{Aa}$ & $38.6 \mathrm{Ba}$ \\
Crotalaria & $13.6 \mathrm{Ac}$ & $20.2 \mathrm{Ac}$ \\
Pigeon pea & $17.4 \mathrm{Ab}$ & $25.0 \mathrm{Bb}$ \\
Pigeon pea + Crotalaria & $15.2 \mathrm{Abc}$ & $20.2 \mathrm{Bc}$ \\
\hline $\mathrm{CV}(\%)$ & & 8,3 \\
\hline
\end{tabular}

The same letters in the columns do not differ statistically, by the test of Tukey at $5 \%$ probability.

Table 3. Nematodes associated with yam roots in the field, 90 days after incorporation of crotalaria and pigeon pea to soil surface.

\begin{tabular}{lcc}
\hline \multirow{2}{*}{ Treatments } & S. bradys & R. reniformis \\
\cline { 2 - 3 } & (number of nematodes per gram of roots) \\
\hline Control & $8.0 \mathrm{a}$ & $2.67 \mathrm{a}$ \\
Crotalaria & $0.0 \mathrm{c}$ & $0.33 \mathrm{~b}$ \\
Pigeon pea & $5.0 \mathrm{~b}$ & $3.34 \mathrm{a}$ \\
Pigeon pea + Crotalária & $1.0 \mathrm{c}$ & $0.67 \mathrm{~b}$ \\
\hline $\mathrm{CV}(\%)$ & 20.2 & 19.52 \\
\hline
\end{tabular}

The same letters in the columns do not differ statistically, by the test of Tukey at $5 \%$ probability.

Table 4. Nematodes infecting roots of crotalaria and pigeon pea planted alone and intercropped with yam in the field.

\begin{tabular}{lcc}
\hline Plant species and cropping system & R. reniformis & S. bradys \\
\cline { 2 - 4 } & (number of nematodes per gram of roots) \\
Crotalaria (single) & $0 *$ & 0 \\
Crotalaria (intercropped) & 0 & 0 \\
Pigeon pea (single) & 26 & 0 \\
Pigeon pea (intercropped) & 4 & 0 \\
\hline
\end{tabular}

* Mean of five replications 
Table 5. Soil nematode population at 90 and 120 days after incorporation to soil of fresh aerial parts of crotalaria, pigeon pea and the combination of both.

\begin{tabular}{|c|c|c|c|c|}
\hline \multirow{4}{*}{ Treatments } & \multicolumn{2}{|c|}{ S. bradys } & \multicolumn{2}{|c|}{ R. reniformis } \\
\hline & \multicolumn{4}{|c|}{ Days after green manure incorporation to soil } \\
\hline & 90 & 120 & 90 & 120 \\
\hline & \multicolumn{4}{|c|}{ (number of nematodes per $100 \mathrm{~cm}^{3}$ of soil) } \\
\hline Control & $8 \mathrm{a}$ & $5.5 \mathrm{a}$ & $89 a$ & $105 \mathrm{a}$ \\
\hline Crotalaria & $0 b$ & $\mathrm{Ob}$ & $7 d$ & $19 \mathrm{~d}$ \\
\hline Pigeon pea & $5 \mathrm{a}$ & $6 a$ & $38 b$ & $60 \mathrm{~b}$ \\
\hline Pigeon pea + Crotalaria & $0.3 \mathrm{~b}$ & $1.7 \mathrm{~b}$ & $19 \mathrm{c}$ & $29 \mathrm{c}$ \\
\hline$\overline{\mathrm{CV}(\%)}$ & 11.9 & 19.6 & 8.1 & 18.1 \\
\hline
\end{tabular}

The same letters in the columns do not differ statistically, by the test of Tukey at 5\% probability.

infectivity of $R$. reniformis in pigeon pea plants (Table 4).

Wang et al. (22) and Santana et al. (19) reported that $C$. juncea promotes the efficient control of $R$. reniformis. In this study, S. bradys penetration in crotalaria and pigeon pea roots was not observed. Adesiyan (2) when studying different plant hosts for S. bradys, observed that pigeon pea is a moderate host for S. bradys. In the scientific literature there is no information on the ability of $S$. bradys to reproduce in crotalaria roots.

Yam tubers infected with nematodes were not observed at the first early harvesting period, six months after yam sowing. However, at final harvesting the percentage of tubers infected was 30 and $26.7 \%$ in the conventional planting system and the intercropped planting system with pigeon pea, respectively, and was only $6.7 \%$ for the planting systems intercropped with crotalaria and with the combination of crotalaria and pigeon pea. These results demonstrate the efficiency of the treatments with crotalaria in controlling nematodes associated with yam crop. For treatments with crotalaria and with crotalaria combined with pigeon pea there was a reduction in the populations of $S$. bradys and $R$. reniformis in soil (Table 5). The population of $S$. bradys was low for all treatments. However, low soil nematode populations when not managed in an adequate way can, in a short period of time, become numerous and difficult to control. S. bradys completes its reproductive cycle in 21 days and in favorable conditions can rapidly increase its population (15).

The greater populations of $R$. reniformis in soil were found in the control treatment (T1) and in the treatment with pigeon pea (T3), which presented 105 and 60 nematodes per $100 \mathrm{~cm}^{3}$ of soil, respectively, (Table 5). $R$. reniformis has been pointed out as a future problem for yam crop, which might become the main yam parasitic nematode in Brazil (19).

In studies carried out in yam farming areas in the Recôncavo region of Bahia State, high populations of $R$. reniformis were detected in soil. Therefore, the development of efficient control methods for this nematode becomes necessary.

In the treatments with crotalaria alone and with crotalaria combined with pigeon pea, a significant reduction in the populations of $S$. bradys and $R$. reniformis in soil was observed (Table 5). Crotalaria has the capacity to induce suppression to some species of nematodes, especially $R$. reniformis. This plant liberates root exudates with nematicide properties and might also liberate other compounds with nematicide properties during its decomposition in soil (21). The crotalaria beneficial effects are not restricted only to nematicide effects. Studies have demonstrated an increase in nematophagous fungal populations by the incorporation of $C$. juncea aerial parts to soil, and also an increase in nematode predators $(21,23)$.

The results obtained in all experiments demonstrated the beneficial effect of $C$. juncea for control of plant-parasitic nematodes associated with yam 'da Costa' crop. For all treatments with $C$. juncea, an effective control of $S$. bradys and $R$. reniformis was observed. Therefore, soil amendment with $C$. juncea is a good alternative for controlling these nematodes in soil. The employment of crotalaria alone or in combination with pigeon pea (Cajanus cajan) intercropped with yam demonstrated to be an efficient control method which can be used for the development of sustainable systems for management of S. bradys and $R$. reniformis.

\section{REFERENCES}

1. Acosta, N.; Ayala, A. Pathogenicity of Pratylenchus coffeae, Scutellonema bradys, Meloidogyne incognita and Rotylenchulus reniformis on Dioscorea rotundata. Journal of Nematology, Lawrence, v.7, n.1, p.1-5, 1975.

2. Adesiyan, S. O. Host range studies of the yam nematode, Scutellonema bradys (Investigaciones sobre la gama de hospederos del nematodo del ñame, Scutellonema bradys). Nematropica, Florida. v.6, n.2, p.60-63, 1976 .

3. Alvarenga, R. C.; Costa, L. M. da; Moura Filho, W.; Regazzi, A. J. Características de alguns adubos verdes de interesse para a conservação e recuperação de solos. Pesquisa Agropecuária Brasileira, Brasília, v.30, n.2, p. 175-185, fev. 1995.

4. Akhtar, M.; Mahmood, I. Impact of organic and management and plant-based products on plant-parasitic and microbivorous nematode communitiens. Nematologia Mediterrânea, Bari, v.25, n.1, p. 21-23, 1997.

5. Amabile, R. F; Carvalho, A. M. de; Duarte, J. B.; Fancelli, A. L. Efeito de épocas de semeadura na fisiologia e produção de fitomassa de leguminosas nos cerrados da região do Matogrosso de Goiás. Scientia Agrícola, Piracicaba, v.53, n. 2-3, p.296-303, maio/dez., 1996.

6. Babatola, J. O.; Oyedunmade, E. A. Influence of organic manures and urea on nematode pests of Celosia argentea. Nematologia Mediterrânea, Bari, v.20. n.1, p. 237-239, 1992.

7. Banzatto, D. V.; Kronka, S. do N. Experimentação Agrícola. Jaboticabal: FCAV/UNESP, 1992. 247 p.

8. Bybd, D. W. Jr.; Kirkpatrick, T.; Barker, K. R. An improved technique for clearing and staining plant tissues for detection of nematodes. Journal of Nematology, Lawrence. v.15, n.1, p.142$143,1983$.

9. Coolen, W. A.; D`Herde, C. J. A method for the quantitative extraction of nematodes from plant tissue. Ghent: State Agricultural Research Center, 1972. 77p.

10. Choudhury, M. M; Choudhury, E. N.; Adubação verde e cobertura morta do solo em áreas irrigadas do submédio São Francisco: III controle de nematóides das galhas. Petrolina, Comunicado Técnico, CPATSA, n. 45, dez. 1991. 3p.

11. Garrido, M. da S; Soares, A. C. F; Mendes, L. do N.; Perez, J. O. Novas tecnologias para a produção do inhame (Dioscorea cayennensis Lam.) no Estado da Bahia. Revista Bahia Agrícola, Salvador, v.6, n.1, p.19-22, nov. 2003. 
12. Garrido, M. da S.; Soares, A. C. F. Coimbra, J. L.; Sousa, C. da S. Adubos verdes no controle do nematoide Scutellonema bradys na cultura do inhame (Dioscorea cayennensis Lam.). Fitopatologia Brasileira, Uberlândia, v.29, p.241, 2004.

13. Jatala, P. I; Bridge. Nematode parasites of root and tuber crops. In: Luc, M.; Sikora; Bridge, J. Plant Parasitic Nematodes in Subtropical and Tropical Agriculture. Wallingford: CAB International, p.137-180, 1990.

14. Jenkins, W. R. A. A rapid centrifugal-flotation technique for separating nematodes from soil. Plant Disease Report, Beltsville.v.48, p.692, 1964.

15. Kwoseh, C.; Plowright, R. A.; Bridge, J. The yam nematode: Scutellonema bradys. in: Sarr, J. L.; Cook, R.; Bridge, J. (ed.). Resistence to parasitic nematode. Wallingford, CABI, 2002 v.1, p.221-228.

16. Moura, R. M.; Coelho, R. S. B.; Ribeiro, G. P. Estudo etiológico e efeito de 1,2-dibromo-3-cloropropano no controle da casca preta do inhame (Dioscorea cayennensis Lam.). Fitopatologia Brasileira, Brasília v.3, n.1, p.47-53, 1978.

17. Moura, R. M. Doenças do inhame. In: Kimati, H.; Amorin, L.; Bergamin Filho, A.; Camargo, L. E. A.; Rezende, J. A. M. (eds). Manual de Fitopatologia. São Paulo: Ceres, 1997. p. $463-471$.
18. Moura, R. M.; Pedregosa, E. M. R.; Guimarães, L. M. P. Novos dados sobre a etiologia da casca preta do inhame no nordeste do Brasil. Nematologia Brasileira, Brasília, v.25, n.2, p.235-237, 2001.

19. Santana, A. A. D.; Moura, R. M \& Pedrosa, E. M. R. Efeito da rotação com cana-de-açúcar e Crotalaria juncea sobre populações de nematóides parasitos do inhame-da-Costa. Nematologia Brasileira, Brasília, v.1, n.27, p.13-16, 2003.

20. Santos, E. S. dos. Inhame (Dioscores ssp) aspectos básicos da cultura. João Pessoa: EMEPA-PB, Sebrae, 1996. 158p.

21. Wang, K-H.; Sipes, B. S.; Schmitt, D. P. Suppression of Rotylenchulus reniformis by Crotalaria junces, Brassica napus and Tagetes erecta. Nematropica, Florida.v.31, n.2, p. 235-249, 2001

22. Wang, K-H.; Sipes, B. S.; Schmitt, D. P. Crotalaria as a cover crop for nematode management: A review. Nematropica, Florida. v.32, n.1, p.35-57, 2002.

23. Wang, K-H.; McSorley, R; Marshall, A. J; Gallaher, R. N. Nematode community changes associated with decomposition of $\mathrm{Cro}$ talaria juncea amendment in litterbags. Applied Soil Ecology, Oxford. v.27, n.1, p.31-45, 2004.

24. Widmer, T. L.; Mitkowski, N. A.; Abawi, G. S. Soil organic matter and management of plant-parasitic nematodes. Journal of Nematology, Lawrence v.34, n.4, p. 289-295, 2002. 